\title{
Muslim Tourist Perceived Value in the Hospitality and Tourism industry Riyad Eid and Hatem El-Gohary
}

\begin{abstract}
:
Perceived value is a subjective and dynamic construct that varies among different customers and cultures. Although perceived customer value has been studied by many researchers, no research has been done into the measurement of Muslim Tourist Perceived Value (MTPV) where Muslim tourist evaluates both traditional and religious aspects of value. By means of a multi-dimensional procedure, the authors developed a scale of measurement of MTPV through 24 items grouped into six dimensions: quality, price, emotional, social, Islamic physical attributes, and Islamic nonphysical attributes. The importance of the proposed constructs was theoretically justified. Using a sample of 537 Muslim tourists, the constructs were tested and validated. The results supplies tourism companies with a number of operative factors that may be essential if they are to remain competitive in a dynamic marketplace. This study is probably the first to provide an integrative perspective of MTPV constructs in the hospitality and tourism industry.
\end{abstract}

Keywords: Customer Value, Muslim, Tourism and Hospitality and Scale Development 


\section{Introduction}

Delivering value for customers in hospitality and tourism industry is heralded by some as the next source of competitive advantage (see, for example, Al-Sabbahy, Ekinci, and Riley 2004; Prebensen, Woo, Chen, and Uysal 2013; Woodruff 1997; Zamani-Farahani and Henderson 2010). The recent development of publications in the area may give rise to the impression that customer value has become an area of increasing interest to marketers as it has emerged as a key determinant of consumer decision making. According to Choi and Chu (2001) to be successful in the hospitality and tourism industry, companies must provide superior customer value and this must be done in a continuous and efficient way. Furthermore, tourism companies should improve the quality of their services offerings and ensure that the needs and expectations of their customers are being met (Haywood 1983).

In responding to these developments, tourism industry is progressively moving away from mass marketing and is instead pursuing more sophisticated approaches to segmenting tourist markets to address the distinct consumer psychology of a particular target market. As a result, a religious perspective on travel and other purchase decisions is preferable to other segmentation variables such as demographic characteristics of age and life stage, which have traditionally been used to identify market segments (Gardiner, King, and Grace 2013). However, value creation especially in the tourism industry is always a collaborative and interactive process that takes place in the context of a unique set of multiple exchange relationships provided through services (Vargo 2009). This actually calls for a move from thinking of customers as isolated entities to understanding them in the context of their own networks, backgrounds and religions. 
Meanwhile, there are new trends and developments such as the investment and adoption of business practices based on the Islamic principles of Shari'ah "Islamic law" (Essoo and Dibb 2004; Laderlah, Ab Rahman, Awang, and Man 2011; Meng, Tepanon, and Uysal 2008;

Stephenson, Russell , and Edgar 2010; Weidenfeld and Ron 2008; Zamani-Farahani and Henderson 2010; Zamani-Farahani and Musa 2012). For example, Essoo and Dibb (2004) found that religion influences tourism behavior among Hindus, Muslims and Catholics. Weidenfeld and Ron (2008) also found that religion influences the destination choice, tourist product favorites, and selection of religious opportunities and facilities offered. Laderlah, Ab Rahman, Awang, and Man (2011) reported the various features and popular destinations of Islamic tourism as practiced in Malaysia. Finally, Meng, Tepanon, and Uysal (2008) found that tourists select destinations that are supposed to best fulfil their internal desires or preferred destination attributes.

However, although Muslims make up one of the largest tourist markets in the world as Muslim population constitutes an international market of 2.1 billion possible customers (Muslim population worldwide, 2013), the world's Muslim population is projected to grow by about $35 \%$ between 2010 and 2030 (Jafari and Scott 2013), and marketing scholars have long studied "perceived value" and proposed various conceptualizations of the term (Benkenstein, Yavas, and Forberger 2003; Dumand and Mattila 2005; Dumond, 2000; Gallarza and Saura 2006; Holbrook 1994; Nasution and Mavondo 2008; Oh 2003; Peterson 1995; Petrick 2002; Ravald and Gronroos 1996; Sanchez, Callarisa, Rodriguez, and Moliner 2006; Roig, Carlos, Sanchez, Tena, and Angel 2009), perceived value of tourism offering oriented toward this market has not been clearly defined (Laderlah, Ab Rahman, Awang, and Man, 2011; Stephenson, Russell, and Edgar 2010; Zamani-Farahani and Henderson 2010; Zamani-Farahani and Musa 2012). 
Undoubtedly, although academics have built considerable theoretical knowledge on the conceptualization of perceived value, research about its true meaning that applies to different customer groups is still few. Very little is known about what makes up value for different customer groups that come from various cultural backgrounds (e.g., Muslims). Understanding Islamic values must be seen in local contexts as type of "Glocalization" (Robertson 1994; Salazar 2005) and call for a dramatic change that moves the concept of value-in-use to a more descriptive “value-in-context" concept (Vargo 2009). This actually supports Lusch and Vargo's view that "value is always uniquely and phenomenologically determined by the beneficiary" and is also idiosyncratic, experiential, contextual and meaning laden. Certainly this embraces a multiple-perspective (Lusch and Vargo 2011).

Therefore, further explorations are needed to broaden the concept as they should fit to the needs and expectations of Muslim consumers. Islamic tourism also is still in its infancy stage and yet not well established for many researchers as there is a great need for having more wellestablished studies that can be considered as a step toward a theory building in the field of Islamic tourism (Al-Hamarneh and Steiner 2004, Scott and Jafari 2010; Kalesar 2010; ZamaniFarahani and Henderson 2010; Henderson 2008; 2011).

To bridge this gap various conceptual and empirical studies investigating the concepts of Tourist value, and MTPV were studied. Their findings highlight the fact that on top of the traditional dimensions that help in creating value for tourists, there are more factors that have a direct impact on successful creation of MTPV. Model, definitions, techniques and discussion of these factors and how could they affect MTPV are described in the following sections. 


\section{Research Objectives}

The purposes of this research are to identify MTPV dimensions and develop items of measuring these dimensions, empirically validate the scales, and carry out an initial investigation of the relationship, if any, among the MTPV dimensions. The reminder of this paper is organized as follow. First, a review of relevant MTPV literature is presented. This is followed by identification of MTPV dimensions and development of related scales. Empirical validation of the dimensions is presented next. Based on of the exploratory analysis of the statistical relationships among various MTPV dimensions, managerial implications are offered. The paper concludes with recommendations for future extension of this research. 


\section{Literature Review}

\section{Islamic Tourism}

Islamic tourism seems to be a new concept for most of the researchers and practitioners in the field of tourism which is not true as the concept is very old and can be traced to the early days of the Islamic civilization and the Abbasid times. In the early days of the Islamic history, where the Islamic empire covered vast geographical areas of Asia, Africa and parts of Europe, Muslims got the chance of travel across the three continents safely and without any constrains such as passports, borders or even security investigations. After the death of Prophet Mohammed (PBUH), the Islamic empire expanded north into Syria (636 CE), east to Persia and beyond (636 CE), west into Egypt (640 CE), and then to Spain and Portugal (711 CE) (Donner, 2004). Islam arrived in the area known today as Pakistan in $711 \mathrm{CE}$. The Ottoman Empire (the Turkish dynasty that ruled the Ottoman Empire from the $13^{\text {th }}$ century to its dissolution after World War I) expanded into the Balkan area, taking present day Greece, Bulgaria, Romania, Albania, Serbia, Macedonia, Montenegro, Bosnia, and Hungary. The Ottomans laid siege to Vienna in $1683 \mathrm{CE}$ but were defeated; from 1699 to $1913 \mathrm{CE}$, wars and insurrections pushed the Ottoman Empire back until it reached the current European border of present-day Turkey (Jafari and Scott 2013).

Islamic tourism is deeply rooted with the Islamic Shari'ah where every Muslim is demanded to visit the holy city of Makah (in Kingdom of Saudi Arabia) to conduct Hajj (the fifth pillar of Islam) if he/she can afford to do that financially and physically. Accordingly, any Muslim that does not actually live in that holy city needs to conduct tourism activities to fulfill his/her Shari'ah requirements. Furthermore, millions of Muslims travel to the holy city of Makah every year to perform Umrah (Jafari and Scott 2013). Furthermore, Quranic evidence (Islam's holy book) has been presented regarding the vital importance of travel. The Holy Quran explains in 
Surat Al-Ankabout (literally, The Spider): "Travel through the earth and see how Allah did originate creation; so will Allah produce a later creation: for Allah has power over all things", (Surat Al-Ankabout, verse number 20”. Therefore, based on this quote from Qur'an, Muslims are encouraged to do so for historical, social, and cultural encounters, to gain knowledge, to associate with others, to spread God's word, and to enjoy and appreciate God's creations (Timothy and Iverson 2006).

However, Muslims practice two different types of tourism activities. First pilgrimage-tourism activities or what is called Hajj. Hajj in Islam is performed in the Kingdome of Saudi Arabia within a specific geographical territory (Almasha'er Almoukadasa) include the holy mosque in Makkah, Arafat, Muzdalifah and Mina. It is performed in specific period, from the 8th to the 13th of the twelfth month (Dhul-Hijja) according to the Hegira calendar. Allah (SWT) Says in the holy Quran, (Surat Albakara), verse number 197: "Al-Hajj Ashoron Maalomat" which means that Hajj is performed only at a particular time of the year (Eid, 2102). Muslims who are taking place in this great event should act in a good manner. Allah says in the holy Quran, chapter 2 (Surat Albakara), verse number 197: "If any one undertakes that duty therein, Let there be no obscenity, nor wickedness, nor wrangling in the Hajj". It means that whoever decides to go for Hajj should have good manners, so, there shouldn't be any immortality, sensuality or arguments in Hajj.

Undoubtedly, in Kingdom Saudi Arabia, as the Hajj destination, all management organizations and hotel properties have the relevant requirements that are needed by Muslim tourists, such as prayer times and locations where mosques can be found. Tourism operators have also provided their staff with training about cross-cultural communication and informed them how to accommodate or treat Muslim tourists with respect. As Muslims typically observe a dress code, 
avoid free mixing and eat Halal food, all hotels in KSA offer separate recreational facilities and serve Halal food (Eid 2012).

The second type of tourism activities that could be practiced by Muslims called Islamic tourism and this is the core theme of this article. According to Jafari and Scott (2013), Islamic tourism is essentially a new "touristic' interpretation of pilgrimage that merges religious and leisure tourism. Thus, it is "unlike mass tourism which for Muslims is 'characterized by hedonism, permissiveness, lavishness",' (Sonmez 2001, p. 127). Islamic travel instead is proposed as an alternative to this hedonic conceptualization of tourism. Undoubtedly, religious beliefs influence and direct Muslim adherents to travel to particular sites and influence their attitudes and behavior, perceptions, and perhaps emotions at those sites (Jafari and Scott 2013). Therefore, trends in forms of religious tourism may vary between adherents of different faiths.

Distinctive requirements of Muslims in terms of food, daily prayers, and travel patterns (Timothy and Iverson 2006) call for certain adjustments in the tourism offering of most destinations. For example, Islam necessities certain practices regarding health and hygiene such as washing before performing the daily prayers, identifies what food is permissible to be consumed; for example, pork and alcohol are proscribed, and how some food should be prepared; Muslims are to eat Halal meat which requires Zabh (Slaughter) of an animal according to Islamic specifications (Hodge 2002). As these practices remain important when traveling, a number of authors have discussed how hotels can become Shari'a compliant to help in creating Muslim Tourist Value (Henderson 2010; Jafari and Scott 2013; Ozdemir and Met 2012). 


\section{Customer Perceived Value}

Customer perceived value is the ultimate result of marketing activities and is a first-order element in relationship marketing (Oh 2003; Dumond 2000; Peterson 1995; Prebensen, Woo, Chen, and Uysal 2013; Ravald and Gronroos 1996; Sanchez, Callarisa, Rodriguez, and Moliner 2006). It is defined as a trade-off between total perceived benefits and total perceived sacrifices and is considered as an abstract concept (Weinstein \& Johnson, 1999); hence, its interpretation varies according to the context (Sweeney and Soutar 2001). The term perceived is suggested to reflect the experiential view, in which it is believed that value judgment is dependent upon the consumers' experience. Some studies have treated value as a dependent measure rather than a driver of purchase behavior (Heeler, Nguyen, and Buff 2007). Others (Prebensen, Woo, Chen, and Uysal 2013; Tanford, Baloglu, and Erdem 2012) looked at it as a predictor variable.

\section{Conceptualizations of Customer Perceived Value}

In recent years customer perceived value has been the object of interest by many researchers in hospitality and tourism industry. Some studies treated perceived value as two crucial dimensions of consumer behavior (the functional value): one of benefits received (economic, social and relationship) and another of sacrifices made (price, time, effort, risk and convenience) by the customer (see for example Bigne, Andreu, Kuster, and Blesa 2005; Oh 2003; Sa'nchez, Callarisa, Rodr'guez, and Moliner 2006).

Undoubtedly, hospitality and tourism activities need to resort to fantasies, feelings and emotions to explain the tourist purchasing decision. Many products have symbolic meanings, beyond tangible attributes, perceived quality, or price (Havlena \& Holbrook, 1986). Furthermore, as perceived value is a subjective and dynamic construct that varies among different tourists and 
cultures at different times, it is necessary to include subjective or emotional reactions that are generated in the consumer mind (Havlena and Holbrook 1986; Bolton and Drew 1991;

Prebensen, Woo, Chen, and Uysal 2013; Sweeney and Soutar 2001). Havlena \& Holbrook have demonstrated the importance of the affective component in the experiences of buying and consuming in leisure, aesthetic, creative and religious activities (Havlena and Holbrook 1986). Dumand and Mattila (2005) also found that affective factors, especially hedonic and pleasure are related to a cruise vacationers' value perception. Recently, Lee, Lee, and Choi (2011) highlighted the importance of emotional value in addition to functional value for festival goers. They suggested that future research should examine other potential factors that might influence perceived value.

Therefore, many studies adopt a wider view that treats the concept of customer perceived value as a multidimensional construct (See for example: De Ruyter, Wetzels, Lemmink, and Mattson 1997; Prebensen, Woo, Chen, and Uysal, 2013; Rust, Zeithaml, and Lemmon 2000; Sweeney, Soutar, and Johnson 1999; Sweeney and Soutar 2001; Woodruff 1997). For example, Sweeney, Soutar, and Johnson (1999) identify five dimensions: social value (acceptability), emotional value, Functional value (price/value for money), functional value(performance/quality), and functional value (versatility); Benkenstein, Yavas, and Forberger (2003) conclude that satisfaction with leisure services is a function of cognitive and emotional (psychological) factors; and Petrick's (2002) scale consists of five components: behavioral price, monetary price, emotional response, quality, and reputation. Finally, to measure the onsite perceived value, Prebensen, Woo, Chen, and Uysal (2013) suggested four distinct dimensions: emotional, social, quality/performance, and price/value for money. 
Table 1 shows studies that have adopted the multidimensional approach in the hospitality and tourism industry, and the proposed dimensions of the construct. All the authors utilized the two underlying dimensions of perceived value: cognitive (functional) and affective (emotional) (AlSabbahy, Ekinciv, and Riley (2004); Benkenstein, Yavas, and Forberger 2003; Bradley and Sparks 2012; Duman and Mattila 2005; Gallarza and Saura 2006; Lee, Lee, and Choi 2011; Nasution and Mavondo 2008; Petrick 2002; Sanchez, Callarisa, Rodriguez, and Moliner 2006; Prebensen, Woo, Chen, and Uysal 2013). In this sense, the cognitive dimension refers to the rational and economic valuations made by individuals. The quality of the product and of the service would form part of this dimension. The affective or emotional dimension is less developed, but captures the feelings or emotions generated by the products or services.

\section{Please insert Table 1 about here}

However, although these studies provide empirical evidence of the existence of the cognitive and affective dimensions of perceived value, none of them studies the overall perceived value of a purchase from an Islamic perspective. The study of value from an Islamic perspective in particular is important, as in the Islamic faith, the boundaries of the spiritual and secular are transcended. The holy book Qur'an provides guidance in all aspects of human activity, so religion influences the direction of tourism choices that individuals are making about alternative forms of its development and practice (Jafari and Scott, 2013). Therefore, evaluation of the value of tourism products in the case of Islamic tourism participation entails a completely different process due to the requirements of the Islamic Shari'ah. Participation of Muslims in tourism activities requires acceptable goods, services and environments. Therefore, any attempt to design a scale of measurement of the overall MTPV of a purchase, or to identify its dimensions, must 
not only reflect a structure that identifies functional and affective dimensions but also the Shari'ah-Compliant attributes.

\section{Additional Dimensions for Muslim Tourist Perceived Value (MTPV)}

Undoubtedly, religious identity appears to play an important role in shaping consumption experiences including hospitality and tourism choices among Muslim customers. This is because some religions teach their followers codes of behavior which may encourage or discourage them from being customers to the tourist industry. For example, some people, due to their religious beliefs, find public alcohol consumption to be very offensive (Battour, Ismail, and Battor 2011; Jafari and Scott 2013). It is a religious compulsion for all Muslims to consume products that are permitted by Allah (God) and falls under the jurisdiction of Shari'ah. In Islam, Shari'ahCompliant tourism products generally refer to all such products that are in accordance with the instructions of Almighty Allah (God) and Prophet Mohammad (may peace be upon him). Shari'ah designates the term "Halal" specifically to the products that are permissible, lawful and are unobjectionable to consume. Shari' ah-Compliant tourism products may therefore add value to Muslim consumers' shopping experiences through Islamic benefits that contribute to the value of the shopping experience.

Shari'ah principles are requirements for every Muslim and sensitivity toward application of these principles is important because religious deeds are not acceptable if they are not conducted appropriately. A typical Muslim is expected to do regular prayers in clean environments and fast in Ramadan. In Islamic teachings, Muslims are also expected to abstain from profligate consumption and indulgence (Hashim, Murphy, \& Hashim, 2007). In addition, Shari’ah principles prohibit adultery, gambling, consumption of pork and other haram (forbidden) foods, 
selling or drinking liquor and dressing inappropriately (Zamani-Farahani and Henderson 2010). Actually in the Islamic faith, the boundaries of the spiritual and secular are transcended. The holy book Qur'an provides guidance in all aspects of human activity, so religion influences the direction of tourism choices that individuals are making about alternative tourism packages and destinations. This unifying tendency is also found in the concept of Ummah (The Muslim world community) regardless of country of origin. Therefore, Shari'ah compliance should be a prerequisite for high value tourism experiences for Muslims.

Based on the above discussions, two conclusions can be introduced to help in building an effective scale to measure MTPV. Firstly, the view of perceived value as a cognitive variable is not enough, since it is necessary to incorporate the affective component. Secondly, Muslim tourist evaluates not only the traditional aspects of value (cognitive and affective components) but also the religious identity related aspects that contribute to the value creation. This overall vision underlies the multidimensional approach to MTPV. 


\section{Research methodology}

\section{Data collection}

The generalizability of the study relied on the representativeness of the respondents. Therefore, a representative selection of Muslim tourists was made from a database of Muslim tourists. Several International tourism organizations that are located in UK, Egypt and UAE were contacted to give us access to their Tourist database, of which three prominent ones accepted to give us such access. The three organizations have been reassured that only members of the research team will have access to the data they give and the completed questionnaire will not be made available to anyone other than the research team. A database of Muslim tourists has been made for data collection purposes.

The criteria for selecting tourists to participate were simple. First, tourist should be Muslim. Secondly, tourist should have bought a tourism package during the last two years. Finally, tourists should come from different countries. This technique resulted in a database of 6454 Muslim tourists. A systematic random sampling method has been used to draw a sample of 1000 tourists. A research packet, which contained a covering letter and an anonymous [selfadministering] questionnaire, was e-mailed to the tourists and a web link of the On-line survey has also been given in the e-mail. Some respondents refused to participate to this study as we did not get any reply from them. Unfortunately, no information is available about non respondents and so this source of non-sampling error cannot be controlled. A total of 571 respondents returned questionnaires, but 34 were omitted from analyses due to missing data, leaving a total of 537 useful responses or a $55.59 \%$ overall response rate. This high 55.59 per cent response rate may be explained by two factors: First, the questionnaire was designed in such a way that means 
it takes only 15 minutes to be completed. Second, attempts were made to contact each respondent up to five times via e-mails and phone calls before the person was dropped from the sample.

The sample was dominated by male respondents $(65.2 \%)$ and this is normal since there are some restrictions in Islam which prevent woman from traveling on her own. Furthermore, Islam males are allowed to travel alone, they also make all of the travel decisions and according to the Islamic culture it is not accepted that a female give her e-mail address to a strange. This might explain this result. In terms of age, most were younger than 45 years old [75.4\%], and a few respondent [approximately 9.5\%] were more than 55 years old. Approximately $73.2 \%$ of the respondents had at least some college education, with $35.6 \%$ having earned a post graduate degree. With respect to the income level, $21.0 \%$ of the respondents reported a household income between $\$ 1,000$ and $\$ 1,999$ per month, $24.6 \%$ reported a household income between $\$ 2,000$ and $\$ 3,999$ per month, $17.3 \%$ reported a household income between $\$ 4,000$ and $\$ 5,999$ per month and $17.5 \%$ reported a household income more than $\$ 6,000$ per month. Finally, we have respondents from 30 different countries which include; Algeria (1.8\%), Bangladesh (3\%), Egypt (12.1\%), France (3\%), India (2.4\%), Indonesia (3.1\%), Iran (1.4\%), Iraq (3.2\%), Ireland (2.3\%), Jordan (4.0\%), KSA (2.6\%), Kuwait (3.1\%), Lebanon, Libya (2.2\%), Malaysia (3.2\%), Morocco (3.1\%), Oman (2.5\%), Pakistan (2.3\%), Palestine (2.4\%), Qatar (3.1\%), Singapore (2.6\%), Spain (2.5\%), Sudan (2.1\%), Syria (2.5\%), Tunisia (3\%), Turkey (3.1\%), UAE (9.2\%), UK (6.7\%), USA (2.6\%) and Yemen $(2.4 \%)$. 


\section{Research Instrument Development_Measures}

We measured the six constructs (functional value (quality), functional value (price), emotional value, social value, Islamic physical attributes value and Islamic non-physical attributes value) by multiple-item scales adapted from previous studies. All items were operationalized using a fivepoint Likert-type scale.

Firstly, in conceptualizing the cognitive value (functional value), the original Sweeney \& Soutar (2001) scale of cognitive value is used in this study. According to Sweeney \& Soutar (2001) cognitive value is a dimension that consists of two constructs - quality and price. Four five-point Likert-type questions have been used to measure each one of them. Secondly, in conceptualizing the affective value (Emotional), we follow Sanchez, Callarisa, Rodriguez, and Moliner (2006) defining it as a dimension that consists of two constructs - emotional value and social value measured by four five-point Likert-type questions. We borrowed or adapted these items from Gallarza and Saura (2006), Sanchez, Callarisa, Rodriguez, and Moliner (2006) and Sweeney and Soutar (2001).

Finally, in conceptualizing the Islamic value, the development of the research instrument was based mainly on new scales, because we could not identify any past studies directly addressing this construct. However, three main sources have been used for this purpose; Qur'an (Islam's holy book) and Sunnah (teachings, guidance and practices of Prophet Mohammad) and a thorough review of the literature in which the variable is used theoretically or empirically (Battour, Ismail, and Battor 2011; Eid, 2007; Hashim, Murphy, and Hashim 2007; Laderlah, Ab Rahman, Awang, and Man 2011; Stephenson, Russell , and Edgar 2010; Zamani-Farahani and Henderson 2010; Zamani-Farahani and Musa 2012). For example, studies conducted by Battour, 
Ismail, \& Battor (2011) identified Islamic attributes of destinations that may attract Muslim tourists such as the inclusion of prayer facilities, Halal food, Islamic entertainment, Islamic dress codes, general Islamic morality and the Islamic call to prayer. This study recommended that Islamic attributes of destination should be developed for the purpose of empirical research. Ozdemir and Met (2012) also argued that as Muslims typically observe a dress code and avoid free mixing, some hotels in Turkey offer separate swimming pool and recreational facilities. However, the three sources lead us to divide this dimension into two basic constructs- Islamic physical attribute value and Islamic non-physical attributes value that have been measured by four five-point Likert-type questions.

Two consecutive rounds of pre-testing were conducted in order to insure that respondents could understand the measurement scales used in the study: First, the questionnaire was reviewed by five academic researchers experienced in questionnaire design and next, the questionnaire was piloted with four tourism experts known to the researchers. The pilot took the form of an interview where the participants were first handed a copy of the questionnaire and asked to complete it and then discuss any comments or questions they had. The outcome of the pre-testing process was a slight modification and alteration of the existing scales, in light of the scales context under investigation. 


\section{Analysis and Results}

The evidence generated from the literature suggests that there are distinct aspects of value. This section discusses the process used to establish the content for these dimensions and to validate the scale psychometrically and theoretically. The process follows Churchill's (1979) approach for developing measures of multiple-item marketing constructs. After the development of an initial set of items, scale purification stage was undertaken.

\section{Reliability Analysis}

First, the psychometric properties of the constructs were assessed by calculating the Cronbach's alpha reliability coefficient and the items-to-total correlation (Nunnally and Bernstein 1994). These coefficients are represented for each of the constructs in (Table 2). All scales have reliability coefficients ranging from 0.868 to 0.955 , which exceed the cut-off level of 0.60 set for basic research (Nunnally 1978) and used by Eid and El-Gohary 2013; El-Gohary, 2012; and ElGohary, 2010.

\section{Please insert Table 2 about here}

\section{Exploratory Factor Analysis (EFA)}

Next, it is also necessary to indicate that, as recommended by Anderson and Gerbing (1982), prior to testing the full latent model, an exploratory factor analysis (EFA) was conducted using principal components analysis with Varimax rotation. EFA yielded a six distinct factors that accounted for $80.974 \%$ of the variance extracted (Table 3). All items loaded highly on their intended constructs. 


\section{Please insert Table 3 about here}

\section{Confirmatory Factor Analysis (CFA)}

Next, before building a model that will consider all the dimensions of value together, it is also important to highlight, from a methodological point of view, that individualized analyses of each of those dimensions will be made (the measurement model), in order to carry out a prior refinement of the items used in their measurement. Having established the six dimensions of the scale, we conducted a confirmatory factor analysis (CFA). For this research, we chose to use both the structural model (includes all the constructs in one model) and the measurement model (separate model for each construct).

First, as suggested by Bollen (1989), a null model, in which no factors were considered to underlie the observed variables, correlations between observed indicators were zero and the variances of the observed variables were not restricted, was tested against a series of models, namely: a one factor model (suggesting that the observed variables represent a single value dimension), a three factor model (in which price and quality are suggested to represent a single functional dimension rather than two dimensions, emotional and social values are suggested to represent a single emotional dimension rather than two dimensions and Islamic physical attributes and Islamic non-physical attributes are suggested to represent a single Islamic dimension rather than two dimensions), and a six factor model (in which the dimensions are as proposed in the earlier discussion).

The results, shown in Table 4, support the proposed six-factor solution, comprising the quality, price, emotional, social, Islamic physical attributes and Islamic non-physical attributes value 
dimensions. Not only did this model have the lowest $\mathrm{X}^{2}$ and highest adjusted goodness of fit index, but also the highest CFI and the lowest RMSEA.

\section{Please insert Table 4 about here}

Second, we used the measurement model (separate model for each construct) to assess the measurement models. Thus, two dimensions have been considered for cognitive value: the first referring to the quality of the tourism package and the second to the price of the tourism package. Similarly, two dimensions have been considered for formative value: the first referring to the emotional value of the tourism package and the second to social value of the tourism package. Finally, two dimensions have been considered for Islamic value: the first referring to the Islamic physical attributes of the tourism package and the second to the Islamic non-physical attributes of the tourism package.

\section{Cognitive value of the tourism package: Quality}

With respect to the cognitive value of the tourism package, fundamentally it is the quality level of the different aspects of the tourism package that is measured (Table 5). Initially four items were considered. As a result of the confirmatory factor analysis, it was found that the four items form a single factor, and furthermore the resulting model is adequate because the probability associated with chi squared is greater than $0.05(0.061)$, and the t-value of the parameters obtained is always greater than 1.96. The scale is also reliable, the statistic of composite reliability that determines it taking the value 0.90 (Hair, Anderson, Tatham, \& Black, 1998).

\section{Please insert Table 5 about here}




\section{Cognitive value of the tourism package: Price}

The second dimension relating to cognitive value is the price of the tourism package purchased. To measure it four items were used (Table 5). The confirmatory factor analysis determined that the four items were grouped into a single factor. The model grouping these items is adequate, the probability associated with chi-squared being greater than $0.01(0.0311)$, and all the $t$-values associated with the parameters obtained in the model are greater than 1.96. Together with these results, the composite reliability of the factor cognitive value price of the tourism package is also ratified as this reliability attains the value 0.867 (Hair, Anderson, Tatham, and Black 1998).

\section{Affective value of the tourism package: Emotional}

With respect to the emotional value of the purchase, four items were used (Table 5) to measure it. The confirmatory factor analysis determined that the four items were grouped into a single factor. The resulting model is adequate, the probability associated with chi-squared being greater than 0.01 (0.0316), and all the t-values associated with the parameters obtained in the model are greater than 1.96. It is also necessary to indicate that composite reliability of the emotional value exists, the statistic determining it reaching the value 0.935 (Hair, Anderson, Tatham, and Black 1998).

\section{Affective value of the tourism package: Social}

The second dimension relating to affective value is the social value of the tourism package purchased. To measure it four items were used (Table 5). The confirmatory factor analysis determined that the four items were grouped into a single factor. The resulting model is adequate, the probability associated with chi-squared being greater than $0.01(0.020)$, and all the t-values 
associated with the parameters obtained in the model are greater than 1.96. It is also necessary to indicate that composite reliability of the social value exists, the statistic determining it reaching the value 0.899 (Hair, Anderson, Tatham, and Black 1998).

\section{Islamic Value of the tourism package: Physical attributes}

With respect to the Islamic physical attributes value of the tourism package purchased, fundamentally it is the tangible attributes that make Shari'ah-Compliant tourism products that is

measured (Table 5). Initially four items were considered. As a result of the confirmatory factor analysis, it was found that the four items form a single factor, and furthermore the resulting model is adequate because the probability associated with chi squared is greater than 0.01 (0.016), and the t-value of the parameters obtained is always greater than 1.96. The scale is also reliable, the statistic of composite reliability that determines it taking the value 0.919 (Hair, Anderson, Tatham, and Black 1998).

\section{Islamic Value of the tourism package: Non-physical attributes}

The last of the dimensions considered refers to Islamic non-physical attributes value. Similarly, it is the intangible attributes that make Shari'ah-Compliant tourism products. To measure it four items were used (Table 5). As a result of the confirmatory factor analysis, it was found that the four items form a single factor, and furthermore the resulting model is adequate because the probability associated with chi squared is greater than $0.01(0.110)$, and the t-value of the parameters obtained is always greater than 1.96. The scale is also reliable, the statistic of composite reliability that determines it taking the value 0.955 (Hair, Anderson, Tatham, and Black 1998). 


\section{Convergent Validity Analysis}

Convergent validity describes the extent to which indicators of a specific construct converge or share a high proportion of variance (Hair, Black, Babin, Ralph, and Ronald 2006). Convergent validity can be assessed by three criteria (Fornell and Larcker 1981; Hair, Black, Babin, Ralph, and Ronald 2006; Čater and Čater 2010). Firstly, factor loading for an item is at least 0.7 and significant. Secondly, construct reliability is a minimum of 0.7 (See Table 2). Finally, average variance extracted (AVE) for a construct is larger than 0.5. Table 6 summarizes the results of the convergent validity analysis. Note that all of the scales had an acceptable convergent validity.

\section{Please insert Table 6 about here}

\section{Discriminant Validity Analysis:}

Correlation matrix and square root of AVE were used to assess the discriminant validity of constructs. To meet the requirements for satisfactory discriminant validity, the square root of AVE of each construct should be higher than the correlations between any combinations among any two pairs of constructs in the model as recommended by Fornell \& Larcker (1981). This indicates that each construct should share more variance with its items than it shares with other constructs. Table 7 illustrates that shows that the variances extracted by the six constructs (AVE) were greater than any squared correlation among constructs (the factor scores as single item indicators have been used to calculate the between-constructs correlations); this implied that constructs were empirically distinct confirmed the discriminant validity of those four constructs.

\section{Please insert Table 7 about here}




\section{Correlation among the Constructs:}

One of the main objectives of this study is to set a valid structure for the MTPV constructs and to carry out an initial investigation of the relationship, if any, among these constructs. According to this research, there are six constructs constitute the MTPV model. First of all, it is clearly noted that all of the correlations among the constructs of the MTPV are positive and significant (see table 7). These significant positive correlations also have major implications for marketing and tourism people, as they suggest the notion that the MTPV constructs should be implemented holistically rather than piecemeal to get better MTPV. 


\section{Discussion and Implications}

The purpose of this article is to (a) Identify MTPV constructs and develop scales of measuring these constructs and (b) Carry out an initial investigation of the relationship, if any, among the MTPV constructs.

The present research was an attempt to explore the MTPV dimensions of a tourism consumption experience, in relation to previous consumer and tourism research. This study makes a number of contributions to the study of customer value. Previous studies mostly examined absolute customer value from the customers' perspective. There has been little empirical research that examines customer value from the perspectives of the Muslim customers. In service industries, like tourism, the consumption experience is intangible, dynamic, and subjective (Bolton and Drew 1991; Havlena and Holbrook 1986; Jayanti and Ghosh 1996; Sweeney and Soutar 2001) and therefore it is not acceptable to assume that the dimensions of value are applicable to different customers and cultures.

The reliabilities, factor structure and validity tests indicate that the 24-item MTPV scale and its six dimensions have sound and stable psychometric properties. The scale demonstrates that Muslim consumers assess products, not just in functional terms of expected quality of the tourism product, price of the tourism product, the enjoyment delivered from the tourism product (emotional value) and what the tourism product communicates to others (social value); but also in terms of providing tangible attributes that result on the delivery of Shari'ah-Compliant tourism products such as Halal food (Islamic physical attributes value) and the availability of Shari'ah compatible art, fun and entertainment tools (Islamic non-physical attributes value). 
A Muslim tourist's decision should not be seen from a purely rational point of view. The experiential view provides new keys to the valuation made by Muslim tourists and therefore to the most important attributes that will later affect their buying behavior. Cognitive elements (quality and price) and affective elements (emotions and social recognition) play a fundamental role but it would not be possible to understand the behavior of Muslim tourists without incorporating the Islamic attributes into the study. The availability of such Islamic attributes (Physical and Non-Physical) are considered very important when a Muslim decides to buy a tourism product (WTM, 2007). Therefore, the Muslim tourists may not select a particular tourism product based on the absence of such attributes (Battour, Ismail, and Battor 2011). Islamic attributes represent the availability of Islamic norms and practices which are relevant to tourism at the destination.

From a theoretical point of view, therefore, this study supports the experiential view proposed by Holbrook and Hirschman (1982). This means that the cognitive, the affective and the Islamic attributes components play a fundamental role in explaining purchase and consumption behaviors of the Muslim Tourist. In the specific case of the perceived value variable, cognitive, affective and Islamic attributes components have been identified. The cognitive components are related to the traditional view of perceived value, as being a comparison between "'getting', (through perceived quality) and "giving" (through the price). The affective components are centered on the internal feelings generated by the experience of purchase and consumption and by the repercussions in the consumer's social environment (Sanchez, Callarisa, Rodriguez, and Moliner 2006). The Islamic attributes components are related to the development of Islamic-oriented tourism products as the absence of Islamic attributes at the destination may be a source of worry to themselves and those with whom they interact (Syed 2001). 
With regard to the business implications, recognition of the importance of the different dimensions of MTPV should enable tourism and hospitality companies to develop more sophisticated positioning strategies. Our results show the importance of Islamic physical attributes and Islamic non-physical attributes value on Muslim consumer's willingness to buy a tourism product normally considered as functionally and affectively oriented. This has substantial implications for marketing strategy. For example, tourism and hospitality companies should develop a hospitality and tourism market that represents Shari'ah compliant tourism products. Such initiatives illustrate the potential tourism companies have in establishing and developing forms of hospitality and tourism grounded in principles and behavioral codes that represent national society and culture. Tourism and hospitality institutions can improve the chance of their selection by identifying and marketing their ability to meet the Muslim tourist needs.

An additional implication related to the urgent need for tourism organizations to readdress its hospitality and tourism products in association with culturally oriented particularities and distinctions. Such innovation requires investment in product development, research and marketing, integral to a broader trend that ought to consider Islam as a cultural philosophy. Merging elements of the conservative Islamic lifestyle with the modern tourism industry could present new tourism options and spheres (Al-Hamarneh and Steiner 2004). 


\section{Limitations and Suggestions for Future Research}

As with any study, there are certain limitations that should be recognized. First, we assessed MTPV using only six constructs; quality, price, emotional, social, Islamic physical attributes and Islamic non-physical attributes; while there is evidence that MTPV is a much broader construct that might include reputation (Nasution and Mavondo 2008) Aesthetics (Gallarza and Saura 2006) and religiosity (Zamani-Farahani and Musa 2012). Second, the data are cross-sectional in nature and hence it is not possible to determine causal relationships. Finally, while the sample size and the approach to data analysis indicate that our findings are robust, there is always a lingering question as to whether these results are generalizable or are specific to the participated countries. We believe that although the current sample is big and diverse enough and our findings may be representative of Muslim tourists, we urge other researchers to replicate the study and get replies from different countries and especially to use the measures developed in this study to test their robustness.

The direction for future research, which emerged from our findings, is to improve our understanding of the MTPV in other types of business. For example, each MTPV discussed in this study warrants more in depth study in other services industries such as banking and insurance. Given the importance associated with the MTPV, a potentially fruitful area would be to develop the quantification of MTPV into an "index of practice" so that tourism companies could determine the level of performance on a time-based approach. The results from an audit, with regard to the index, could pinpoint areas that need attention and improvement.

Future research may choose to focus on one or more of the Islamic attributes to generate an indepth knowledge to inform both theoretical and practical applications. Researchers could use these factors to assess the success of tourism companies in attracting Muslim tourism. On the 
other hand, the MTPV measurement must be subjected to review, critique, and discussion for an extended period before getting general acceptance. Additional items might be tried in each category. Finally, different constructs could be tried to measure the MTPV effect. To this end, a very promising research approach is to study the on sequences of MTPV for the tourist's postpurchase behaviors. More specifically we suggest analyzing the causal relationship between perceived value and satisfaction and loyalty. 


\section{References}

Al-Hamarneh, A., and Steiner, C. (2004). "Islamic Tourism: Rethinking The Strategies Of Tourism Development In The Arab World After September 11,2001. Comparative studies of South Asia." Africa and the Middle East, 24(1): 173-182.

Al-Sabbahy, H., Ekinci, Y., and Riley, M. (2004). “An investigation of perceived value dimensions: implications for hospitality research.” Journal of Travel Research, 42(3): $226-234$.

Battour, M. M., Ismail, M. N., and Battor, M. (2011). "The impact of destination attributes on Muslim tourist's choice.” International Journal of Tourism Research, 13(6): 527-540.

Benkenstein, M., Yavas, U., and Forberger, D. (2003). "Emotional and cognitive antecedents of customer satisfaction in leisure services: the case of Rostock Zoo.” Journal of Hospitality and Leisure Marketing, 10(3/4): 173-184.

Bigne, E., Andreu, L., Kuster, I., and Blesa, A. (2005). “Quality market orientation: tourist agencies' perceived effects.” Annals of Tourism Research, 32 (4): 1022-1038.

Bollen, K. A. (1989). Structural equations with latent variables. New York: John Wiley and Sons.

Bolton, R.N., and Drew, J.H. (1991). “A multistage model of customers’ assessments of service quality and value.” Journal of Consumer Research, 17 (4): 375-384.

Bradley, G. L., and Sparks, B. A. (2012). “Antecedents and Consequences of Consumer Value A Longitudinal Study of Timeshare Owners.” Journal of Travel Research, 51(2): 191-204.

Čater, T., and Čater, B. (2010). "Product and relationship quality influence on customer commitment and loyalty in B2B manufacturing relationships.” Industrial Marketing Management, 39(8): 1321-1333. 
Choi, T.Y., and Chu, R. (2001). "Determinants of Hotel Guests's Satisfaction and Repeat Patronage in the Hong Kong Hotel Industry.” International Journal of Hospitality Management, 20 (3): 277-297.

Churchill, G. A. Jr. (1979). “A paradigm for developing better measures of marketing constructs." Journal of Marketing Research, 16(1), 64-73.

De Ruyter, J. K., Wetzels, M., Lemmink, J., and Mattson, J. (1997). “The Dynamics of the Service Delivery Process: A Value-based Approach.” International Journal of Research in Marketing, 14(3): 231-243.

Donner, F. M. (2004). Expansion. In R. C. Martin (Ed.). Encyclopedia of Islam and the Muslim world (Vol. 1, pp. 239-245). NewYork: Macmillan Reference USA.

Dumond, E. J. (2000). "Value management: and underlying framework." International Journal of Operations and Production Management, 20(9): 1062-1077.

Dumand, T., and Mattila, A. S. (2005). "The role of affective factors on perceived cruise vacation value." Tourism Management, 26(3): 311-323.

Eid, R. (2007). “Toward a Successful CRM Implementation In banks: An Integrated Model.” The Service Industries Journal, 27(8), 1021-1039.

Eid, R. (2012). "Towards a high-quality religious tourism marketing: the case of hajj service in Saudi Arabia." Tourism Analysis, 17(4): 509-522.

Eid, R., and El-Gohary, H. (2013). “ The Impact of E-Marketing Use on Small Business Enterprises' Marketing Success: The Case of UK Companies.” The Service Industries Journal, 33 (1): 31-50.

El-Gohary, H. (2010). “ Expanding TAM and IDT to understand the adoption of E-Marketing by small business enterprises." International Journal of Customer Relationship Marketing and Management, 1 (3):56-75. 
El-Gohary, H. (2012). "Factors affecting E-Marketing adoption and implementation in tourism firms: An empirical investigation of Egyptian small tourism organizations.” Tourism Management, 33 (5): 1256-1269

Essoo, N., and Dibb, S. (2004). "Religious Influences on Shopping Behaviour: An Exploratory Study." Journal of Marketing Management, 20(7): 683 - 712.

Fornell, C., and Larcker, D. (1981). "Evaluating structural equation models with unobservable variables and measurement error." Journal of Marketing Research, 18 (1): 39-50.

Gallarza, M ., and Saura, I. (2006). "Value Dimensions, Perceived Value, Satisfaction and Loyalty: an Investigation of University Students' Travel Behavior.” Tourism Management, 27(3): 437-452.

Gardiner, S., King, C. and Grace, D. (2013). “Travel Decision Making: An Empirical Examination of Generational Values, Attitudes, and Intentions.” Journal of Travel Research, 52(3): 310-324.

Hair, J. F. Jr., Anderson, R. E., Tatham, R. L., and Black, W. C. (1998). Multivariate data analysis, 5th edition, Upper Saddle River NJ: Prentice-Hall.

Hair, J., Black, B, Babin, B., Ralph, A. and Ronald, T. (2006). Multivariate Data Analysis, 6th edition, London: Prentice-Hall.

Hashim NH, Murphy J, and Hashim, NM. (2007). "Islam and Online Imagery on Malaysian Tourist Destination Websites." Journal of Computer-Mediated Communication, 12(3): $1082-1102$.

Havlena, W. J., and Holbrook, M. B. (1986). "The Varieties of Consumption Experience: Comparing Two Typologies of Emotion in Consumer Behavior." Journal of Consumer Research, 13(3): 394-404. 
Haywood, K.M., (1983). “Assessing the Quality of Hospitality Services.” International Journal Hospitality Management, 2 (4): 165-177.

Heeler, R. M., A. Nguyen, and C. Buff. (2007). "Bundles = discount?Revisiting Complex Theories of Bundle Effects." Journal of Product \& Brand Management, 16 (7): 492-500. Henderson, J. C. (2008). "Representations of Islam in Official Tourism Promotion.” Tourism Culture and Communication, 8(3): 135-145.

Henderson, J. C. (2010). "Sharia-compliant hotels." Tourism \& Hospitality Research, 10(3), 246254.

Henderson, J. C. (2011). "Religious Tourism and Its Management: The Hajj in Saudi Arabia." International Journal of Tourism Research, 13(6): 541-552.

Hodge, D. R. (2002). "Working with Muslim youths: Understanding the values and beliefs of Islamic discourse." Children \& Schools, 24(1): 6-20.

Holbrook, M. B., and Hirschman, E. (1982). “The Experiential Aspects of Consumption: Consumer Fantasies, Feelings, and Fun.” Journal of Consumer Research, 9(2): 132-140. Holbrook, M. B. (1994). The Nature of Consumer Value. In R. T. Rust, \& R. L. Oliver (Eds.), Service quality: new directions in theory and practice. Sage: Newbury Park, CA.

Jafari, J., and Scott, N. (2013). "Muslim world and its tourisms." Annals of Tourism Research, http://dx.doi.org/10.1016/j.annals.2013.08.011

Jayanti, R. K., and Ghosh, A. K. (1996). "Service Value Determination: An Integrative Perspective." Journal of Hospitality and Leisure Marketing, 34(4): 5-25.

Laderlah, S., Ab Rahman, S., Awang, K., and Man, Y. (2011). A Study on Islamic Tourism: A Malaysian Experience, 2nd International Conference on Humanities, Historical and Social Sciences IPEDR vol.17, IACSIT Press, Singapore. 
Lee, J. S., Lee, C. K., and Choi, Y. (2011). "Examining the role of emotional and functional values in festival evaluation." Journal of Travel Research, 50(6): 685-696.

Liang, C., and Wang, W. (2004). “Attributes, Benefits, Customer Satisfaction and Behavioral Loyalty- An Integrative Research of Financial Services Industry in Taiwan.” Journal of Services Research, 4(1): 57-91.

Lusch, R. and Vargo, S. (2011). "Viewpoint Service-dominant logic: a necessary step.” European Journal of Marketing, 45 (7/8): 1298-1309

Meng, F., Tepanon, Y., and Uysal, M. (2008). "Measuring tourist satisfaction by attribute and motivation: The case of a nature-based resort.” Journal of Vacation Marketing, 14(1): 4156.

Muslim population worldwide. (2013). Retrieved 23 January, 2013, from http://www.islamicpopulation.com/

Nasution, H., and Mavondo, F. (2008). “Customer Value in the Hotel Industry: What Managers Believe they Deliver and What Customer Experience.” International Journal of Hospitality Management, 27(2): 204-213.

Nunnally, J. (1978). Psychometric Theory. New York, Mc Graw Hill.

Nunnally, J., and Bernstein, I.H. (1994). Psychometric theory (3rd ed.). London: McGraw Hill. Oh, H. (2003). Price Fairness and its Asymmetric Effects on Overall Price, Quality, and Value Judgments: The Case of a Upscale Hotel. Tourism Management, 24(4), 241-249.

Ozdemir, I., and Met, O. (2012). The expectations of Muslim religious customers in the lodging industry: The case of Turkey. In A. Zainal, S. Radzi, R. Hashim, C. Chik, \& R. Abu (Eds.), Current issues in hospitality and tourism research and innovation (pp. 323-328). London: Taylor and Francis. 
Peterson, R. A. (1995). "Relationship marketing and the consumer." Journal of the Academy of Marketing Science, 23(4): 278-281.

Petrick, J. F. (2002). “Experience Use History as a Segmentation Tool to Examine Golf Travelers' Satisfaction, Perceived Value and Repurchase Intentions.” Journal of Vacation Marketing, 8(4): 332-342.

Poria, Y., Butler, R., and Airey, D. (2003). "Tourism, religion and religiosity: A holy mess." Current Issues in Tourism, 6(4): 340-363.

Prebensen, N., Woo, E., Chen, J. and Uysal, M. (2013). "Motivation and Involvement as Antecedents of the Perceived Value of the Destination Experience." Journal of travel research, 52(2): 253-264

Ravald, A., and Gronroos, C. (1996). "The Value Concept and Relationship Marketing.” European Journal of Marketing, 30(2): 19-30.

Robertson, R. (1994). “Globalization or glocalization?.” Journal of International Communication, 1: 33-52.

Roig, F., Carlos, J., Sanchez, J., Tena, M., and Angel, M. (2009). “Perceived value and customer loyalty in financial services.” The Service Industries Journal, 29(6): 775-789.

Rust, T., Zeithaml, V., and Lemmon, K. (2000). Driving customer equity. New York: The Free Press.

Salazar, N. (2005). “Tourism and glocalization: “Local”' tour guiding.” Annals of Tourism Research, 32(3): 628-646.

Sanchez, J., Callarisa, J., Rodriguez, M., and Moliner, A. (2006). "Perceived Value of the purchase of a tourism product." Tourism Management, 27(4): 394-409.

Scott, N., and Jafari, J. (2010). Bridging Tourism Theory and Practice: Tourism in the Muslim World. Vol,2. Emerald Group Publishing. 
Sonmez, S. (2001). Tourism Behind the veil of tourism: Women and development in the Middle East. In Y. Apostolopoulos, S. Sonmez, \& D. J. Timothy (Eds.), Women as producers and consumers of tourism in developing regions (pp. 113-142). Westport:Praeger.

Stephenson, L., Russell, K., and Edgar, D. (2010). "Islamic hospitality in the UAE: indigenization of products and human capital.” Journal of Islamic Marketing, 1 (1): 9-24.

Sweeney, J. C., Soutar, G. N., and Johnson, L. W. (1999). “The Role of Perceived Risk in the Quality-Value Relationship: A Study in a Retail Environment.” Journal of Retailing, 75(1): 77-105.

Sweeney, J. C., \& Soutar, G. (2001). “Consumer Perceived Value: The Development of Multiple Item Scale.” Journal of Retailing, 77(2): 203-220.

Syed, O. A. (2001). Catering to the needs of Muslim Travelers. Paper presented at the Second Conference of Ministers from Muslim Countries, Tourism: Challenges and Opportunities, Kuala Lumpur, 10-13 October.

Tanford, S., Baloglu, S. and Erdem, M. (2012). "Travel Packaging on the Internet: The Impact of Pricing Information and Perceived Value on Consumer Choice.” Journal of Travel Research, 51(1): 68-80.

Timothy, D., and Olsen, D. H. (2006). Tourism, Religion and Spiritual Journeys. Abingdon: Routledge.

Vargo, S. (2009). "Toward a transcending conceptualization of relationship: a service-dominant logic perspective.” Journal of Business \& Industrial Marketing, 24(5/6): 373-379.

Weinstein, A., and Johnson, W. C. (1999). Designing and delivering superior customer value: Concepts, cases, and applications. Boca Raton, FL: St. Lucie Press.

Weidenfeld, A., and Ron, A. (2008). "Religious needs in the tourism industry." Anatolia: International Journal of Tourism and Hospitality Research, 19(2): 18-22. 
Woodruff, B. R. (1997). “Customer value: the next source for competitive advantage.” Journal of the Academy of Marketing Science, 25(2): 139-153.

Zamani-Farahani, H. (2009). The impacts of crises on tourism development: case of Iran. In International conference: Positioning planning in the global crises, Bandung, Indonesia, November: 12-13.

Zamani-Farahani, H., and Henderson, J. C. (2010). "Islamic tourism and managing tourism development in Islamic societies: the cases of Iran and Saudi Arabia.” International Journal of Tourism Research, 12(1): 79-89.

Zamani-Farahani, H. and Musa, G. (2012). "The relationship between Islamic Religiosity and Residents' Perceptions of Socio-Cultural impacts of Tourism in Iran: Case Studies of Sare'in and Masooleh.” Journal of Tourism Management, 33(4): 802-814.

\section{ACKNOWLEDGMENT}

The authors sincerely thank the editor and the anonymous JTR reviewers for their constructive and valuable comments and suggestions. 
Table 1: Dimensions of Perceived Customer Value

\begin{tabular}{|c|c|}
\hline Author & Dimensions \\
\hline Petrick (2002) & $\begin{array}{l}\text { - } \text { Behavioral price } \\
\text { - Monetary price } \\
\text { - Emotional response } \\
\text { - Quality, and reputation }\end{array}$ \\
\hline $\begin{array}{l}\text { Benkenstein, Yavas, and Forberger } \\
\text { (2003) }\end{array}$ & $\begin{array}{l}\text { - } \text { Cognitive Factors } \\
\text { - Emotional (psychological) factors }\end{array}$ \\
\hline $\begin{array}{l}\text { Al-Sabbahy, Ekinciv and Riley } \\
\text { (2004) }\end{array}$ & $\begin{array}{l}\text { - Acquisition value } \\
\text { - } \quad \text { Transaction value }\end{array}$ \\
\hline Dumand and Mattila (2005) & $\begin{array}{l}\text { - Novelty } \\
\text { - Control } \\
\text { - Hedonics }\end{array}$ \\
\hline Gallarza and Saur (2006) & $\begin{array}{l}\text { - } \text { Efficiency } \\
\text { - Service quality } \\
\text { - Social value } \\
\text { - Play } \\
\text { - } \text { Aesthetics }\end{array}$ \\
\hline $\begin{array}{l}\text { Sanchez, Callarisa, Rodriguez, and } \\
\text { Moliner (2006) }\end{array}$ & $\begin{array}{l}\text { - Functional value of the travel agency } \\
\text { - Functional value of the contact personnel } \\
\text { - Functional value (quality) } \\
\text { - Functional value price } \\
\text { - Emotional value }\end{array}$ \\
\hline
\end{tabular}




\begin{tabular}{|c|c|}
\hline & - Social value \\
\hline Nasution and Mavondo (2008) & $\begin{array}{l}\text { - } \text { Reputation for quality } \\
\text { - Value for money } \\
\text { - Prestige }\end{array}$ \\
\hline Lee, Lee and Choi (2011) & $\begin{array}{ll}\text { - } & \text { Emotional values } \\
\text { - } & \text { Functional values }\end{array}$ \\
\hline Bradley and Sparks (2012) & $\begin{array}{l}\text { - } \text { Consumer experience } \\
\text { - } \quad \text { Product Experience } \\
\text { - } \quad \text { Consumption experience } \\
\text { - } \quad \text { Learning experience }\end{array}$ \\
\hline $\begin{array}{l}\text { Prebensen, Woo, Chen and Uysal } \\
\text { (2013) }\end{array}$ & $\begin{array}{ll}\text { - } & \text { Emotional } \\
\text { - } & \text { Social } \\
\text { - } & \text { Quality/performance } \\
\text { - } & \text { Price/value for money }\end{array}$ \\
\hline
\end{tabular}


Table 2: Measure of constructs' reliability

\begin{tabular}{|c|c|c|}
\hline Constructs & Number of Items & Alpha \\
\hline Qualitya & 4 & .901 \\
\hline Price $^{\mathbf{a}}$ & 4 & .868 \\
\hline Emotional $^{\mathbf{b}}$ & 4 & .934 \\
\hline Social $^{\mathbf{b}}$ & 4 & .899 \\
\hline Islamic Physical Attributes $^{\mathbf{c}}$ & 4 & .919 \\
\hline Islamic Non-physical Attributes ${ }^{\mathbf{c}}$ & 4 & .955 \\
\hline \multicolumn{3}{|l|}{$\begin{array}{l}{ }^{\text {a }} \text { Cognitive Value } \\
\text { b Affective Value } \\
\text { c Islamic Value }\end{array}$} \\
\hline
\end{tabular}


Table 3: Results of Factor Analysis for Value Dimensions

\begin{tabular}{|c|c|c|c|c|c|c|}
\hline \multirow[b]{2}{*}{ Value Dimensions } & \multicolumn{6}{|c|}{ Component } \\
\hline & 1 & 2 & 3 & 4 & 5 & 6 \\
\hline The tourism package purchased was well organized & & & & & .712 & \\
\hline The quality of the tourism was maintained throughout. & & & & & 737 & \\
\hline The tourism package had an acceptable level of quality. & & & & & .847 & \\
\hline The tourism package purchased was well made & & & & & 673 & \\
\hline The tourism package was a good purchase for the price. . & & & & & & .741 \\
\hline The tourism package purchased was reasonably priced. & & & & & & .745 \\
\hline The price was the main criterion for my decision. & & & & & & .769 \\
\hline The tourism package purchased was economical. & & & & & & .740 \\
\hline I am comfortable with the tourism package purchased. & & .751 & & & & \\
\hline I felt relaxed about the tourism package purchased. & & .810 & & & & \\
\hline The tourism package purchased gave me a positive feeling. & & .851 & & & & \\
\hline The tourism package purchased gave me pleasure. & & .826 & & & & \\
\hline The tourism package has helped me to feel acceptable. & & & & .737 & & \\
\hline The tourism package improved the way people perceive me. & & & & .832 & & \\
\hline The tourism package purchased gave me social approval. & & & & .809 & & \\
\hline Many people that I know purchased the tourism package. & & & & .733 & & \\
\hline Availability of prayer facilities. & & & .826 & & & \\
\hline Availability of Halal food. & & & .869 & & & \\
\hline Availability of a copy of the Holy Qur'an in hotel room. & & & .792 & & & \\
\hline Availability of Shari'ah compatible toilets. & & & .849 & & & \\
\hline Availability of segregated services. & .901 & & & & & \\
\hline Availability of Shari'ah compatible television channels. & .915 & & & & & \\
\hline Availability of Shari'ah compatible entertainment tools . & .919 & & & & & \\
\hline Availability of art that does not depict the human forms. & .883 & & & & & \\
\hline Initial Eigenvalues & 10.262 & 3.572 & 1.935 & 1.490 & 1.169 & 1.006 \\
\hline
\end{tabular}




\begin{tabular}{|c|c|c|c|c|c|c|}
\hline \% of Variance & 42.758 & 14.882 & 8.061 & 6.210 & 4.869 & 4.192 \\
\hline Cumulative \% & 42.758 & 57.741 & 65.702 & 71.912 & 76.781 & 80.974 \\
\hline
\end{tabular}


Table 4: Comparative Analysis of Models of Various Dimensionalities

\begin{tabular}{|c|c|c|c|c|c|}
\hline Model & $\mathbf{X}^{2}$ & DF & AGFI & CFI & RMSEA \\
\hline Null & 6544.75 & 252 & 0.323 & 0.462 & 0.216 \\
\hline Three Factors & 4157.80 & 249 & 0.549 & 0.666 & 0.171 \\
\hline Six Factors & 1344.53 & 237 & 0.831 & 0.905 & 0.093 \\
\hline \multicolumn{3}{|c|}{ Statistic } & \multicolumn{3}{|c|}{ Suggested } \\
\hline \multicolumn{3}{|c|}{ Adjusted goodness-of- fit index (AGFI) } & \multicolumn{3}{|c|}{$\geq 0.80$} \\
\hline \multicolumn{3}{|c|}{ Comparative fit index (CFI) } & \multicolumn{3}{|c|}{$\geq 0.90$} \\
\hline \multicolumn{3}{|c|}{ Root mean square residual (RMSEA) } & \multicolumn{3}{|c|}{$\leq 0.10$} \\
\hline
\end{tabular}


Table 5: Cognitive value of the different attributes

\section{Quality}

The tourism package purchased was well organized

The quality of the tourism was maintained throughout.

The tourism package had an acceptable level of quality.

The tourism package purchased was well made
.828 (fixed)

$.861(15.22)$

$.859(14.61)$

$.785(13.66)$

Fit of the model

Chi-square $=18.572 ; \mathrm{d}=2 ; \mathrm{p}=0: 061$;

RMSEA $=0: 086 ;$ GFI $=0: 98 ;$ AGFI $=0: 91$

Composite reliability of the Cognitive value of the tourism package: Quality: 0.90

In parentheses, the t-values of each parameter.

\section{Price}

The tourism package was a good purchase for the price. . .828 (fixed)

The tourism package purchased was reasonably priced.

The price was the main criterion for my decision.

The tourism package purchased was economical.

Fit of the model

Chi-square $=45.962 ; \mathrm{d}=2 ; \mathrm{p}=0: 0311$;

RMSEA $=0: 087 ; \quad$ GFI $=0: 962 ; \quad$ AGFI $=$

Composite reliability of the Cognitive value of the tourism package: price: 0.867

In parentheses, the t-values of each parameter.

\section{Emotional value}

I am comfortable with the tourism package purchased.

I felt relaxed about the tourism package purchased.

The tourism package purchased gave me a positive

feeling.

The tourism package purchased gave me pleasure.

Fit of the model
.873 (fixed)

$.898(20.82)$

$.901(20.20)$

$.868(19.56)$

Chi-square=47.577; $d=2 ; p=0: 0316$;

RMSEA $=0: 076 ; \quad$ GFI $=0: 957 ; \quad$ AGFI $=$ 
Composite reliability of the emotional value of the tourism package: 0.935

In parentheses, the t-values of each parameter.

\begin{tabular}{|c|c|}
\hline Social value & \\
\hline The tourism package has helped me to feel acceptable. & .839 (fixed) \\
\hline The tourism package improved the way people perceive & $.902(20.82)$ \\
\hline me. & \\
\hline The tourism package purchased gave me social approval. & $.898(20.20)$ \\
\hline Many people that I know purchased the tourism package. & $.747(19.56)$ \\
\hline Fit of the model & Chi-square $=33.341 ; \mathrm{d}=2 ; \mathrm{p}=0: 0201$ \\
\hline & RMSEA $=0: 087 ;$ GFI $=0: 969 ; \quad$ AGFI $=$ \\
\hline & $0: 845$ \\
\hline
\end{tabular}

Composite reliability of the social value of the tourism package: 0.899

In parentheses, the t-values of each parameter.

\section{Physical Attributes}

Availability of prayer facilities.

.837 (fixed)

Availability of Halal food.

$.893(18.61)$

Availability of a copy of the Holy Qur'an in hotel room.

$.848(16.28)$

Availability of Shari'ah compatible toilets.

$.864(16.10)$

Fit of the model

Chi-square $=31.836 ; \mathrm{d}=2 ; \mathrm{p}=0.016$;

RMSEA = 0:016; GFI= 0:974; AGFI=

$0: 868$

Composite reliability of the Islamic physical attributes value of the tourism package: 0.919

In parentheses, the t-values of each parameter.

\section{Non-physical Attributes}

Availability of segregated services.

.890 (fixed)

Availability of Shari'ah compatible television channels.

$.925(24.75)$ 
Availability of Shari'ah compatible entertainment tools .

Availability of art that does not depict the human forms.

Fit of the model

Chi-square $=8.957 ; d=2 ; p=0.11$;

RMSEA $=0: 081 ;$ GFI $=0: 992 ;$ AGFI $=$

$0: 960$

$.949(27.03)$

$.907(23.62)$
In parentheses, the t-values of each parameter. 
Table 6: Convergent Validity Results

Constructs

Quality

Price

Emotional

Social

Islamic Physical Attributes

Islamic Non-physical Attributes
Composite Reliability AVE

0.900

0.867

0.620

0.935

0.783

0.899

0.719

0.919

0.740

0.955

0.842 
Table 7: Discriminant Validity Results

Correlations

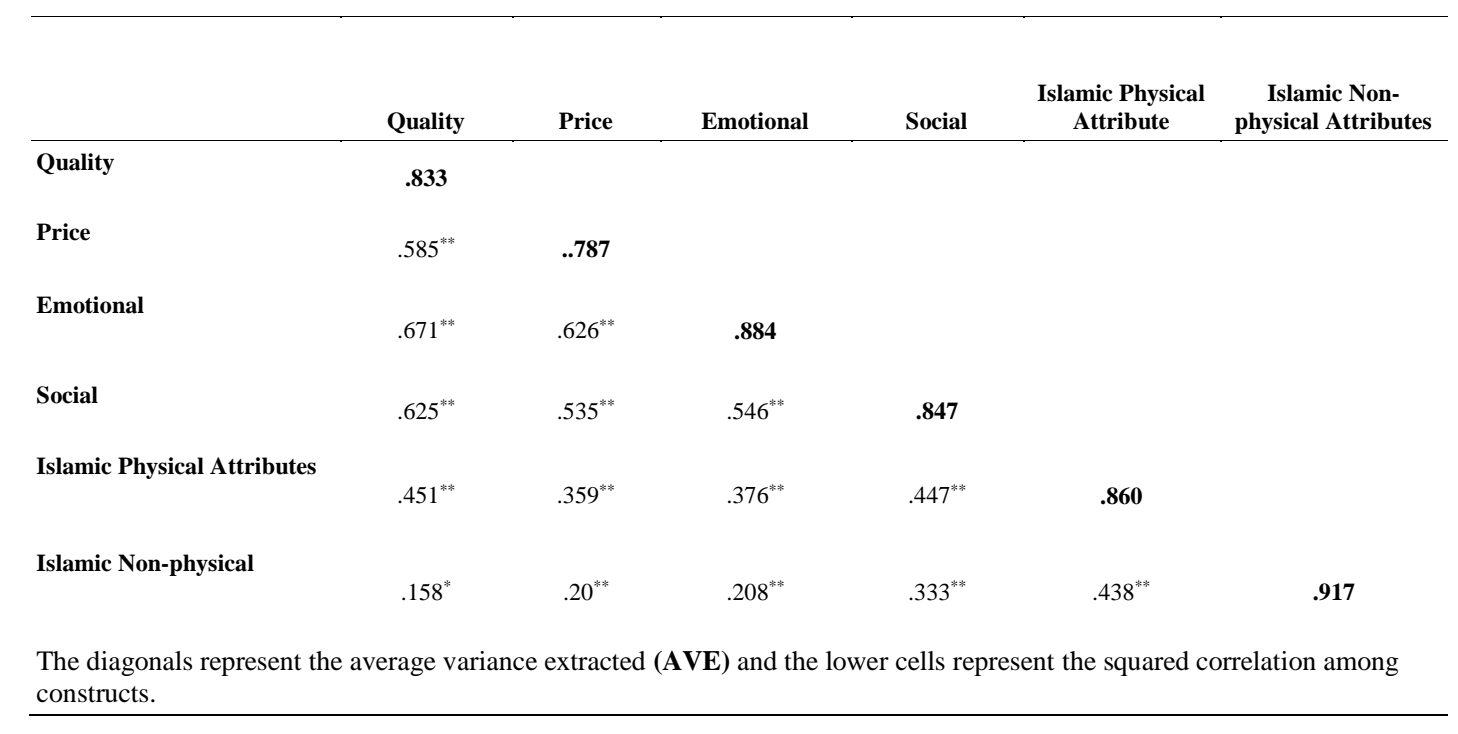

